\title{
20. TEMPERATURE MEASUREMENTS AND HEAT-FLOW ANALYSIS IN HOLE 504B ${ }^{1}$
}

\author{
Gilles Guerin, ${ }^{2.3}$ Keir Becker, ${ }^{4}$ Robert Gable, ${ }^{3}$ and Philippe A. Pezard ${ }^{5}$
}

\begin{abstract}
Drilled $200 \mathrm{~km}$ south of the Costa Rica Rift, DSDP/ODP Hole 504B is the deepest hole ever drilled into young oceanic crust, reaching a maximum depth of $2111 \mathrm{mbsf}$. As the most recent cruise to date to visit this site, Leg 148 offered a new opportunity to investigate such observations from the previous legs as the slow thermal recovery from the flow of cold seawater into the underpressured upper units of basement and the unexplained decrease of measured vertical conductive heat flow with depth (from 196 to $120 \mathrm{~mW} / \mathrm{m}^{2}$ ).

Because of operational troubles during the measurements, the initial data have been corrected, and the actual temperatures show that the aquifer underlying the sediments is still recovering from the inflow of cold seawater. The decrease with depth of the conductive vertical heat flow was also confirmed, but careful observations of the temperature gradient variations suggest that the interval where the change in heat flow occurs coincides with a listric fault at $800 \mathrm{mbsf}$, as inferred from downhole measurements. Even though permeability has been shown to be very low over the basement section, the presence of a narrow highpermeability interval at this depth would be compatible with the uncertainty of these measurements. The circulation of warm fluid within this interval could explain the temperature observations, but it would challenge our understanding of the regional thermal regime.
\end{abstract}

\section{INTRODUCTION}

Drilled $200 \mathrm{~km}$ south of the Costa Rica Rift, Hole 504B is the deepest hole ever drilled into oceanic crust, reaching a maximum depth of $2111 \mathrm{~m}$ below seafloor (mbsf). This site was originally drilled as part of a comparison of sealed crust to that still open to convective cooling by seawater. The high sedimentation rate has produced an exceptionally thick cover over a crust of this age (5.9 Ma), which seals the basement surface from open communication with the sea, and leads one to expect a high geothermal gradient (Cann et al., 1983). Each revisit began with a temperature log or temperature measurements, which have provided an unprecedented set of data for a study of the thermal regime in the surrounding area.

When the hole was first drilled, the measured temperatures in the upper $300 \mathrm{~m}$ of the well indicated a vigorous flow of cold seawater down through the casing, invading the upper levels of the basement (Becker et al., 1983; Gable et al., 1989). Subsequent visits indicated a slow return to equilibrium, until Leg 137 when a renewed downflow was again observed into this aquifer (Gable et al., 1989; Becker, Foss, et al., 1992).

The thermal regime below this unit is thought to be mainly conductive, which is supported by the very low permeabilities measured by Anderson et al. (1985) and Becker (1989). The temperatures measured during Legs 111 and 137, however, showed an average conduc-

'Alt, J.C., Kinoshita, H., Stokking, L.B., and Michael, P.J. (Eds.), 1996. Proc. ODP, Sci. Results, 148: College Station, TX (Ocean Drilling Program).

'Borehole Research Group, Lamont-Doherty Earth Observatory, Palisades, NY 10964, U.S.A. guerin@Ideo.columbia.edu

'Département Hydrologie et Transferts, BRGM, B.P. 6009, 45060 Orléans Cedex 2, France, r.gable@brgm.fr

${ }^{4}$ Division of Marine Geology and Geophysics, Rosenstiel School of Marine and Atmospheric Sciences, University of Miami, 4600 Rickenbacker Causeway, Miami, FL 33149-1098,U.S.A. kbecker@rsmas,miami.edu

SLaboratoire de Mesures en Forage, Institut Méditerranéen de Technologie, Technopôle de Château-Gombert, F-13451 Marseille Cedex 20, France; and Laboratoire de Pétrologie Magmatique, URA CNRS 1277, Faculté des Sciences et Techniques de Saint-Jérôme, Avenue Escadrille Normandie-Niemen. F-13397 Marseille Cedex 20, France. pezard@imtmer1.imt-mrs.fr tive vertical heat flow of $120 \mathrm{~mW} / \mathrm{m}^{2}$ in the lower portion of the borehole (Becker et al., 1983; Gable et al., 1989), whereas the regional surface heat flow, and the values measured in the upper part of the hole, indicate a value of $196 \mathrm{~mW} / \mathrm{m}^{2}$. As yet, no explanation for this observation has been totally satisfactory (Fisher and Becker, 1991; Gable et al., 1995). As the most recent leg to visit Hole 504B, Leg 148 offered one more opportunity to understand the thermal regime in the hole and in the surrounding area.

The temperatures measured just after reentry displayed the same tendency as observed during Leg 140: a return to temperature equilibrium of the adjacent rock formation, with a slower recovery within the aquifer (Gable et al., 1995). Unfortunately, some operational troubles during logging resulted in erroneously high measurements in the upper part of the hole, and cast suspicion on the validity of the recorded data (Alt, Kinoshita, Stokking, et al., 1993). The correction of these original temperatures presented here validates the first observations made on board and also confirms the reduction of vertical heat flow with depth. A new explanation for this observation is also investigated by numerically modeling the possible effects of water circulation through a listric fault suggested by magnetic and electrical downhole measurements at $800 \mathrm{mbsf}$ in Hole 504B.

\section{TEMPERATURE MEASUREMENTS AND CORRECTIONS}

The temperature probe used during Leg 148 was slightly different from the probe run during Legs 111,137 , and 140, but it was based on the same high-precision two-thermistors combination. Used either separately or in series, the two thermistors could measure temperatures with a very high precision for the complete range of temperatures encountered in the borehole.

As mentioned in Alt, Kinoshita, Stokking, et al. (1993), the temperature log was the first operation after reentry in Hole 504B during Leg 148. Different problems were encountered, resulting particularly in the recording of anomalously high temperatures in the upper section of the hole. It appears now that these readings were at least partly attributable to the acquisition system, which was different from the 


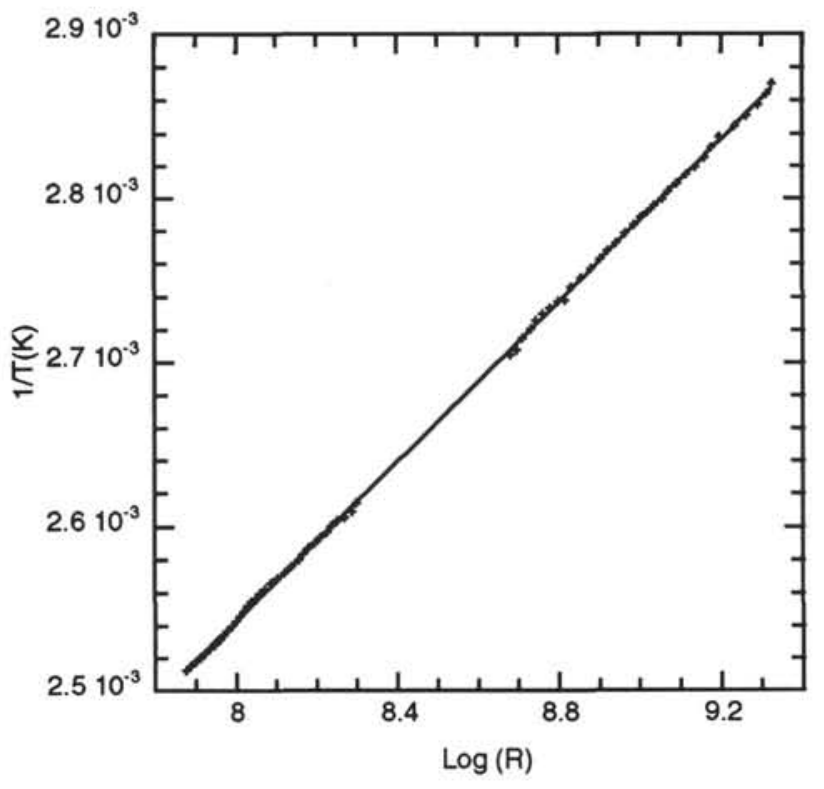

Figure 1. Cross-plot of averaged temperatures from Leg 111 and 137 and resistances measured during Leg 148, used for recalibrations of the thermistors. The continuous line shows the third-order polynomial fit.

original configuration and generated an incorrect calibration of temperature vs. resistance. Moreover, one of the two thermistors stopped working properly for still unknown reasons at about $900 \mathrm{mbsf}$, which disturbed the proper recording by the other thermistor from 900 to 1100 mbsf. At the end of the log, a computer failure destroyed the original data file and some intervals could not be recovered: 590$710,1040-1140$, and 1840-1930 mbsf. A linear profile could be interpolated in those sections dominated by a conductive thermal regime, but vertical gradient and heat-flow computations could not be resolved accurately.

To correct the temperatures estimated during Leg 148 for the different acquisition configuration, it was necessary to evaluate the true calibration law of the thermistors during logging. Once this law is established, the temperatures can be recalculated from the resistances, which are the data actually measured. The temperature $(T)$ vs. resistance $(R)$ relationship is of the form

$$
1 / T(K)=a+(b \times \ln [R])+\left(c \times \ln ^{3}[R]\right),
$$

and, ideally, three couples (resistance, temperature) are necessary to evaluate the constant coefficients $a, b$, and $c$. Because reproducing the actual acquisition system onshore was not possible, we used instead the recorded resistances over the more reliable interval of the hole (500-1000 mbsf) and the temperatures measured at these depths during Legs 111 and 137. This is justified by two reasons: (1) the trend in temperatures recorded during Leg 148 is similar to the trends recorded during the two previous legs, and (2) this interval is thought to be under a purely conductive or at least permanent thermal regime (Gable et al., 1989).

The averaged temperatures from Legs 111 and 137 were calculated for 5-m intervals, as well as a running average for the resistances from Leg 148. The crossplot in Figure 1 shows the resulting ( $1 / T$ vs. $\ln [R])$ function, to which a third-order polynomial least-square fit was applied. The calibration coefficients that result are as follows: $a$ $=0.00081345, b=0.00020492$, and $c=1.7604 \times 10^{-7}$

The calibrated temperature log calculated from the measured resistances and these coefficients is displayed in Figure 2, with the temperatures measured during the most recent legs. The temperature measured at the seafloor $\left(2^{\circ} \mathrm{C}\right)$ would tend to validate the calibration

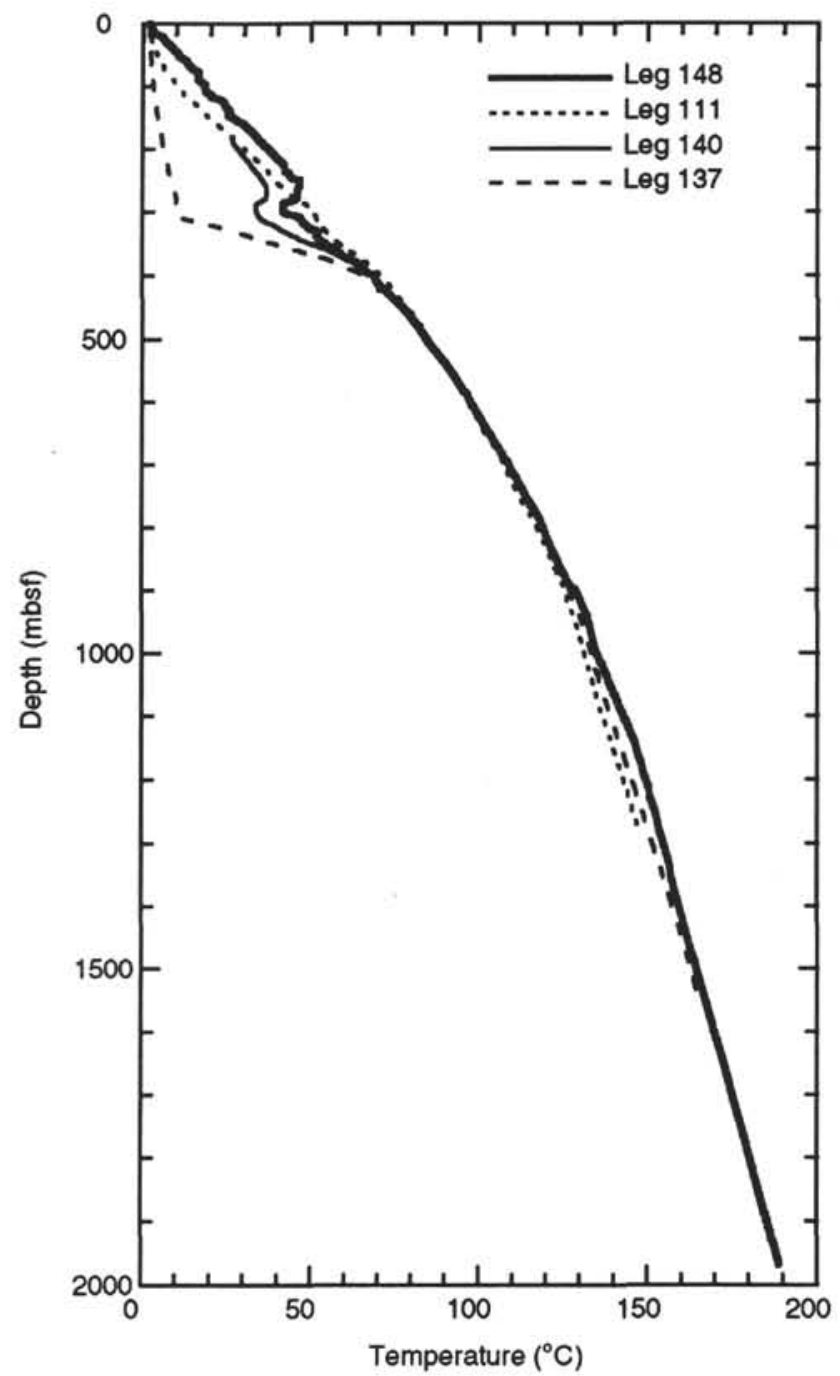

Figure 2. Composite plot of the successive temperature logs during Legs 111, 137,140 , and 148 . The rough fluctuations in the upper $500 \mathrm{~m}$ can be attributed to one faulty thermistor, which definitely stopped functioning below 900 mbsf.

law. The temperature at the bottom of the hole is then $189^{\circ} \mathrm{C}$, slightly higher than initially estimated by Alt, Kinoshita, Stokking, et al. (1993). Owing to the experimental correction method, and to the scattering introduced by the deficient thermistor, the precision is far from the $0.01^{\circ} \mathrm{C}$ that was anticipated, but it can be estimated to be on the order of $1^{\circ} \mathrm{C}$

In Figure 2, we observe the same trend in temperatures as during the most recent preceding Leg 140: the upper part of the hole is still reequilibrating after the downflow of cold seawater within the aquifer (below $275 \mathrm{mbsf}$ ), and this unit is recovering more slowly. The roughness of the variations can be attributed to the defective thermistor, which definitely stopped working below $900 \mathrm{mbsf}$.

\section{TEMPERATURE GRADIENT AND HEAT-FLOW ANALYSIS}

Combining temperature logs with the thermal conductivities measured on about 200 core samples allowed us to infer the variations with depth of the temperature gradient and vertical conductive heat flow in the hole (Fig. 3A, B for Legs 111 and 148). The very strong fluctuations in the top $500 \mathrm{~m}$ are a manifestation of the recovery pro- 
A

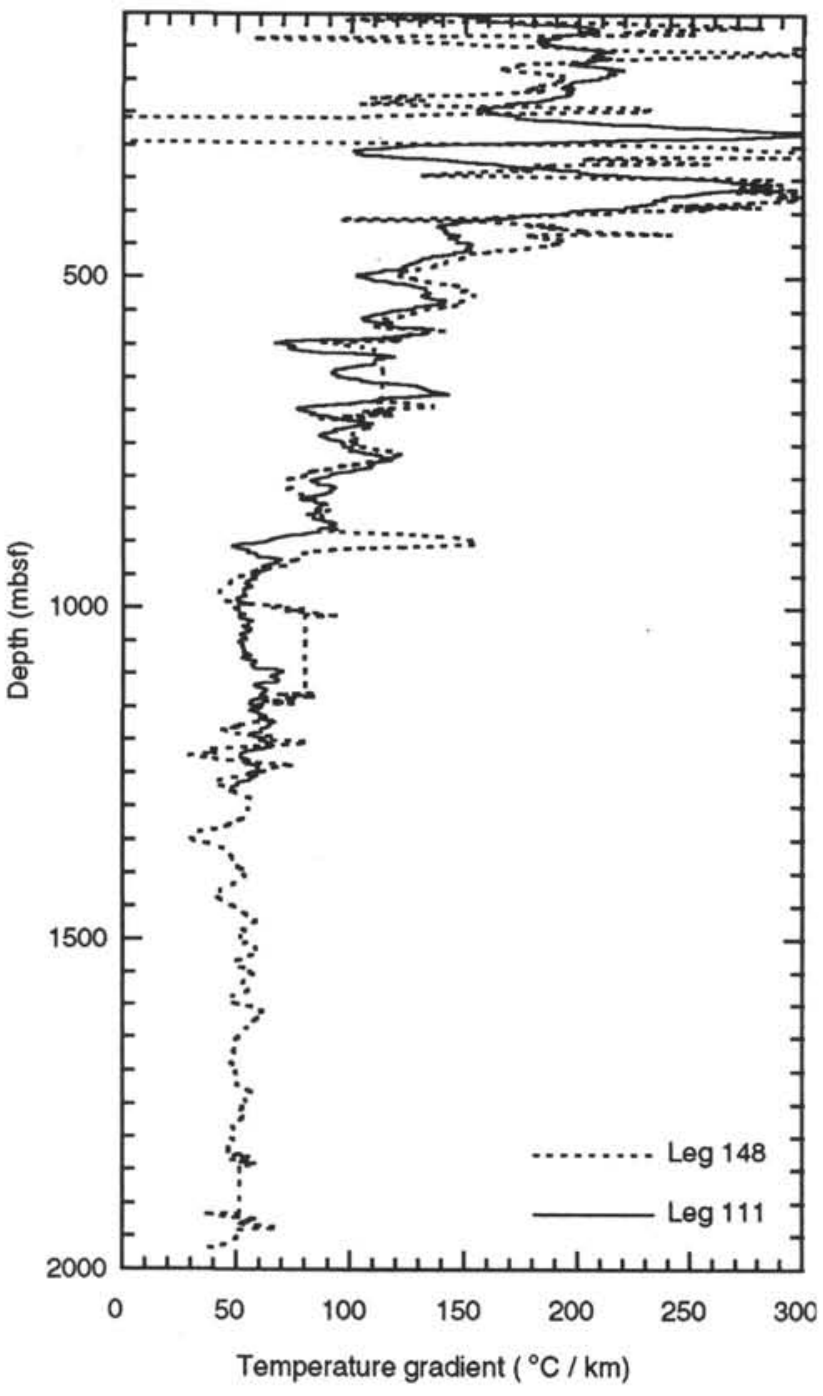

B

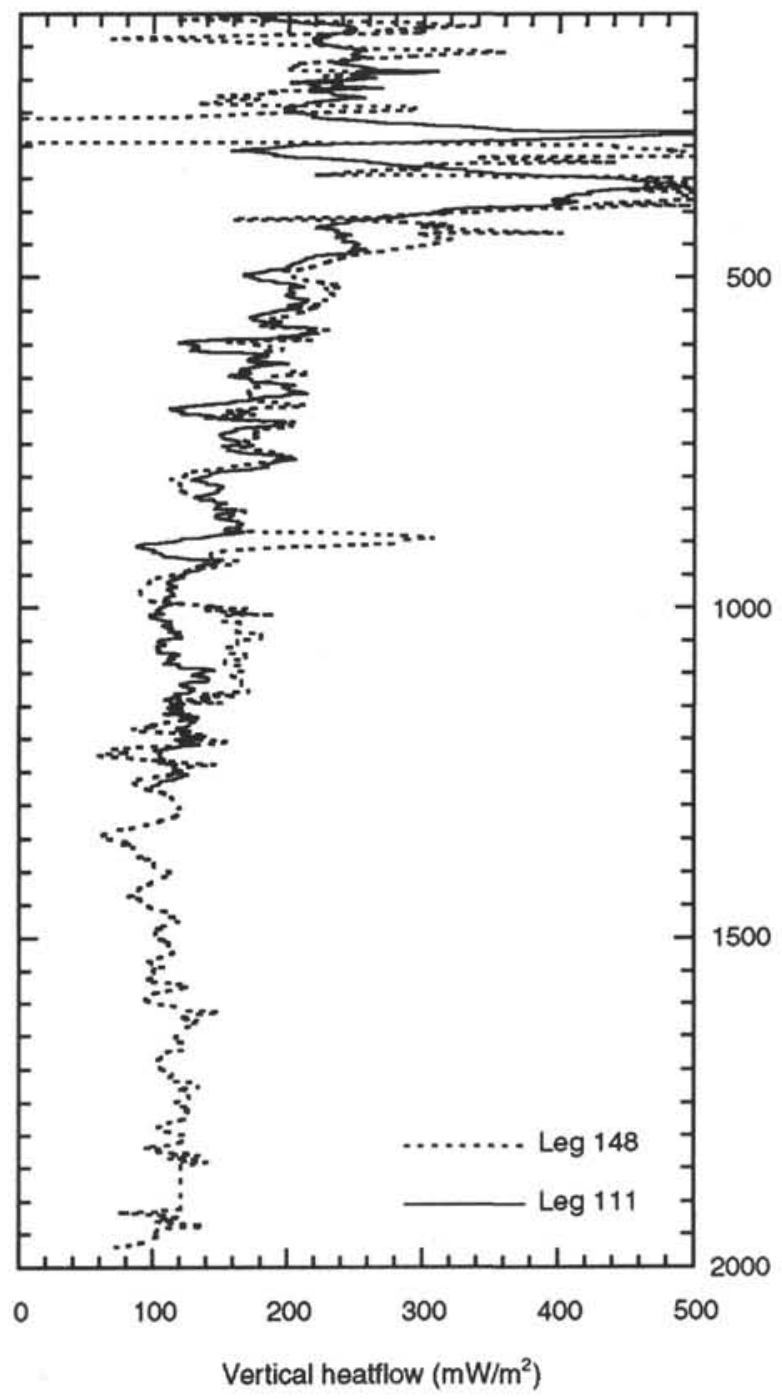

Figure 3. Gradient (A) and heat-flow (B) variations vs. depth measured during Legs 111 and 148.

cess from the disturbance induced previously within the aquifer. Underneath this section, we observed the same systematic decrease of heat-flow values from about 196 to $120 \mathrm{~mW} / \mathrm{m}^{2}$ below $900 \mathrm{mbsf}$.

To understand this observation, we used the same measured thermal conductivities $(\lambda)$ to compute the temperature distributions that would be observed in the two extreme cases of a purely conductive regime with a uniform vertical heat flow of 120 and $196 \mathrm{~mW} / \mathrm{m}^{2}$. Given a vertical heat-flow value of $\Phi$, and knowing the thermal conductivities, the temperature gradient at any depth (where $z=$ depth) can be deduced from Fourier's law for heat conduction:

$$
\mathrm{d} T / \mathrm{d} z=-(\Phi / \lambda) .
$$

The temperature profiles can then be discretely integrated, from $2^{\circ} \mathrm{C}$ at the seafloor to total depth.

In Figure $4 \mathrm{~A}$, the two resulting curves are displayed with the temperatures measured during Leg 148. From bottom to top, the Leg 148 $\log$ follows the trend of the temperature profile for the $120 \mathrm{~mW} / \mathrm{m}^{2}$ conductive heat flow up to 900 mbsf, where it starts shifting toward the $196 \mathrm{~mW} / \mathrm{m}^{2}$ conductive regime, reached at $700 \mathrm{mbsf}$. In Figures $4 \mathrm{~B}$ and $4 \mathrm{C}$, the temperature gradients measured during different legs are plotted vs. the temperature gradient variations calculated using
Equation 2. In Figure 4C, focusing on the 500-1200 mbsf interval, the three measured gradient profiles for Legs 111, 137, and 148 show almost exactly the same variations, and indicate an interval centered roughly at $800 \mathrm{mbsf}$, which seems to be an inlet for heat. More explicitly, the three measured gradient curves show a change in regime over two steps: from 900 to $800 \mathrm{mbsf}$, and from 800 to $700 \mathrm{mbsf}$. The spikes and some anomalous values in the gradient measured during Leg 148 are the effect of the failure of one of the thermistors and do not correspond to any actual data.

\section{A NEW HYPOTHESIS FOR THE REDUCTION OF HEAT FLOW WITH DEPTH}

The depth interval pointed out by Figure 4 overlaps with the transition zone from the overlying pillow basalt to the deeper sheeted dike complex, between 846 and 1055 mbsf (Adamson, 1985). It can also be related to the reducing environment of the lower pillow alteration zone from 585 to $898 \mathrm{mbsf}$, between the oxidative upper pillow alteration zone and the deeper greenschist facies alteration zone (Alt et al., 1985). This association with these two types of transition probably explains the complexity of the thermal processes within this in- 

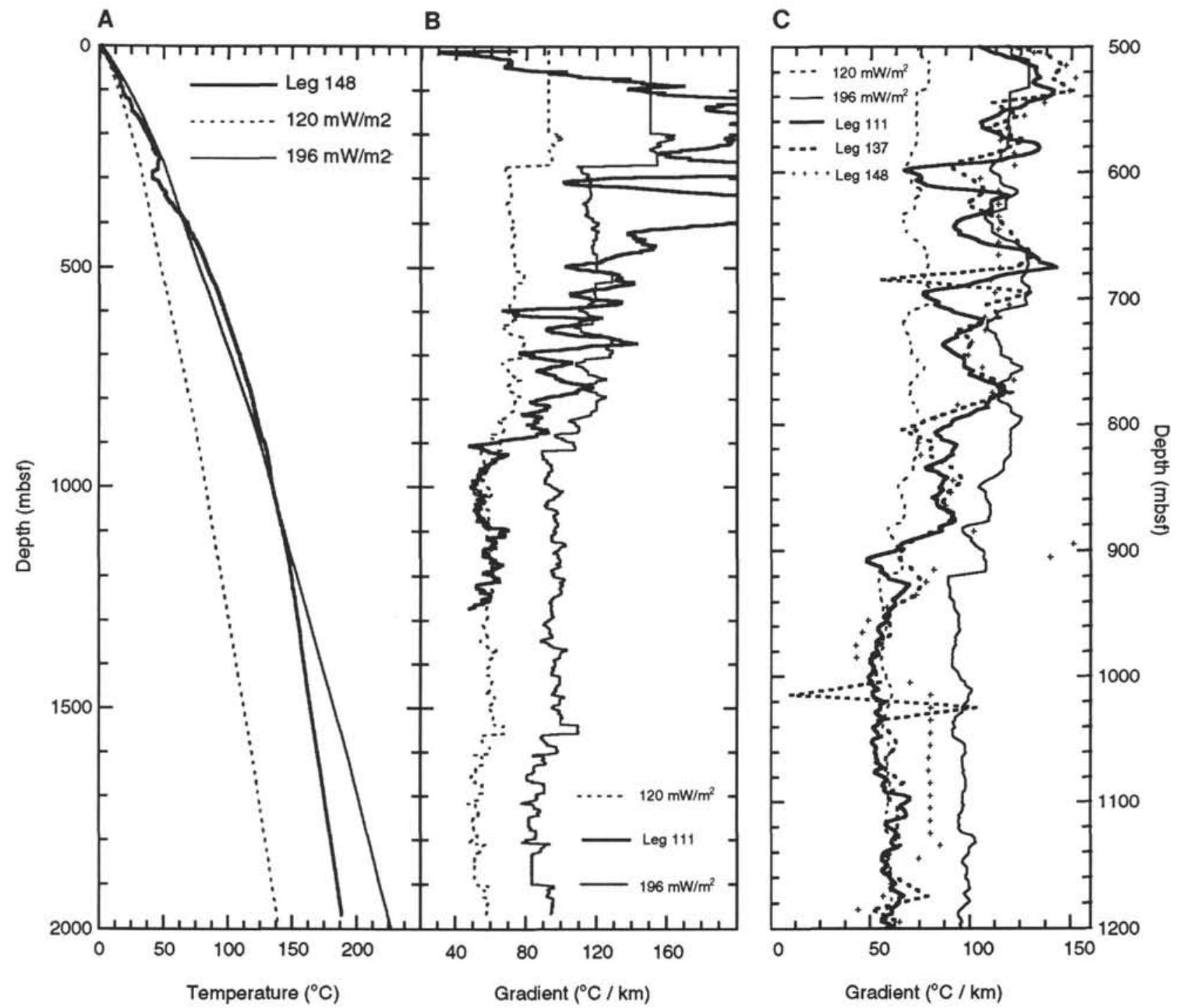

Figure 4. A. Comparison of the temperatures recorded during Leg 148 with the temperatures that would exist in the cases of purely conductive regimes of 120 and $196 \mathrm{~mW} / \mathrm{m}^{2}$. B, C. Comparison of the measured temperature gradient variations with the gradient profiles in cases of purely conductive and uniform regimes of 120 and $196 \mathrm{~mW} / \mathrm{m}^{2}$.

terval. Despite the major changes in most of the physical properties in the same interval, as clearly observed in downhole measurements (Anderson, Honnorez, Becker, et al., 1985), the recorded changes in thermal conductivities cannot explain the change of heat flow in a conductive regime (Gable et al., 1989).

The magnetometer log conducted during Leg 111 showed a change in magnetic inclinations from $15^{\circ}$ above to $8^{\circ}$ at about 800 mbsf (Kinoshita et al., 1989). This suggests that the upper section is rotated, and that Hole 504B may intersect the trace of a listric fault formed within the rift valley. The resistivity logs outline the subhorizontal nature of this fault, and display an interval with lower resistivity and higher porosity at this depth (Pezard, 1990; Pezard and Anderson, 1990). Despite the very low permeability values recorded below 600 mbsf by Anderson et al. (1985) and Becker (1989), we now examine the possibility that the observed variations in vertical heat flow with depth may be related to fluid circulation within this fault zone.

\section{Modeling of Fluid Circulation Within the Fault}

Because simple conduction cannot account for the observations made, and the possible influence of free convection within the borehole is uncertain (Gable, 1989; Fisher and Becker, 1991), the other likely origin of these observations would be hydrothermal. The perfect coincidence of the fault with the interval described above as a possible heat inlet suggests that one possible source of heat would be warm fluids circulating inside the fault.

To investigate this hypothesis, and to estimate what permeability or flow characteristics would be required to reproduce the data, we have used a finite difference two-dimensional numerical model for heat conduction and advection with the following characteristics:

1. The equation used in the algorithm was the standard energy equation for heat conduction and advection inside a volume within surface $A$ : 


$$
-\int_{A} C_{f} \times T \times V_{d} \times \mathrm{nd} A+-\int_{A} \lambda \times \nabla T \times \mathrm{nd} A=0,
$$

where $V_{d}$ is the Darcy velocity, $\lambda$ the thermal conductivity, and $C_{f}$ the specific heat of the fluid.

2 . The modeled section was $2000 \mathrm{~m}$ deep, made of $20 \times 20$ elements (each $100 \mathrm{~m}$ wide and $100 \mathrm{~m}$ thick). The 20 columns played the role of buffers for lateral boundaries effects.

3. The conductivities were determined on the basis of the values measured in the hole, averaged over each 100 -m row, and we assumed a constant velocity horizontal water circulation over a $200-\mathrm{m}$ deep interval centered at 800 mbsf.

4. The initial conditions were the temperature distribution in case of a $120 \mathrm{~mW} / \mathrm{m}^{2}$ uniform vertical heat flow (analogous to Fig. 3A).

The real unknown was the horizontal Darcy velocity:

$$
V_{d}=-(k / \mu) \times \nabla P,
$$

where $\nabla P$ is the horizontal pressure gradient, $k$ is the permeability, and $\mu$ is the fluid viscosity.

After different simulations, we concluded that the flow necessary to reproduce the measured temperatures is as high as $1 \mathrm{~m} / \mathrm{yr}$, which, assuming a permeability of $10^{-15} \mathrm{~m}^{2}$ and a viscosity of $2.0 \times 10^{-4} \mathrm{~Pa}$, represents a horizontal pressure gradient of about $6000 \mathrm{~Pa} / \mathrm{m}$. Figure 5 compares the temperature profile produced by the model to the different field measurements, and displays an almost perfect agreement below $500 \mathrm{mbsf}$ between the model results and the most reliable measurements of Legs 111 and 137.

\section{DISCUSSION AND CONCLUSION}

The approach presented here is one of the most speculative of the different possibilities already investigated by the different authors in trying to explain the thermal regime in Hole 504B. Additional data and verifications would be required before these results could be validated.

One concern is that the permeabilities measured below $500 \mathrm{mbsf}$ are not higher than $4 \times 10^{-16} \mathrm{~m}^{2}$. But the permeability measurements were made over long intervals, and the only measurement made including the fault zone is actually an average permeability of $10^{-17} \mathrm{~m}^{2}$ between 536.5 and 1287.5 mbsf (Anderson et al., 1985), which Becker (1989) eventually reestimated as high as $3.9 \times 10^{-16} \mathrm{~m}^{2}$. A value of $10^{-15} \mathrm{~m}^{2}$ over a 200 - $\mathrm{m}$ interval would imply that the average permeability over the rest of this $750-\mathrm{m}$ section would be at maximum 0.9 $\times 10^{-16} \mathrm{~m}^{2}$. Moreover, the thickness of this interval was chosen for modeling purposes. A more likely configuration would be a thinner high-permeability interval (a few tens of meters) with an even higher permeability. To validate or confirm our hypothesis, it would first be necessary to conduct packer experiments that would straddle a significant section around $800 \mathrm{mbsf}$.

Another concern is that the presence of the fault has been inferred mostly from downhole measurements, without a real confirmation from the core. If there is actually a fault, the fractures may be also filled by alteration minerals. Nonetheless, it is in this interval that the highest penetration rate for coring in the basement has been measured (Becker, Sakai, et al., 1988), which suggests the low mechanical consistency of the rocks.

Finally, if our simulation is correct, this implies that the heat flow at depth is $120 \mathrm{~mW} / \mathrm{m}^{2}$, which contradicts the values predicted for crust of this age. It also implies that this regime, and an analogous water circulation, should extend on a large regional scale to match the observations made of an average surface heat flow of $216 \mathrm{~mW} / \mathrm{m}^{2}$ around Site 504 (Langseth et al., 1988). The mechanisms that would generate such pressure gradients and water flows on a wide regional scale are quite speculative.

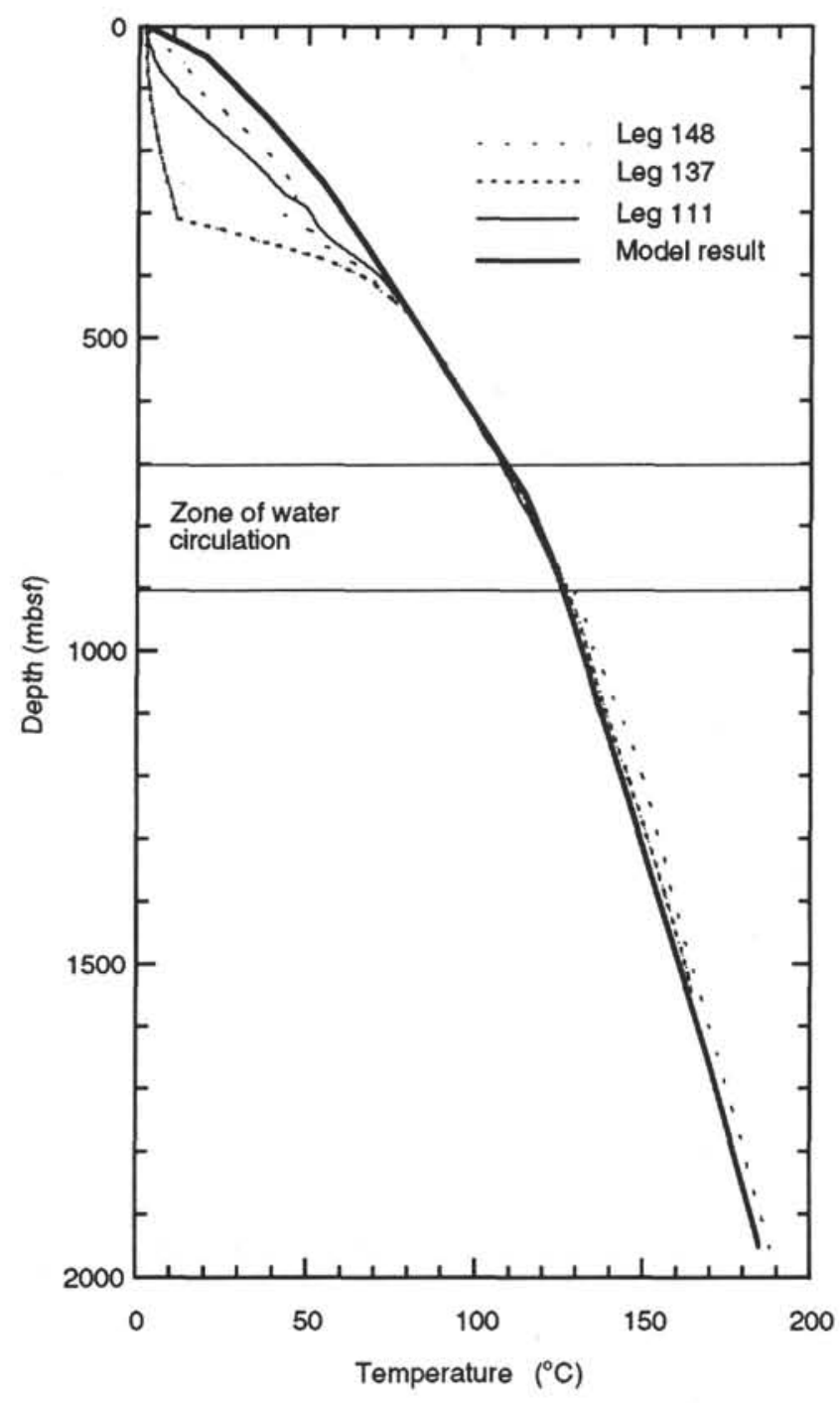

Figure 5. Comparison of the temperatures recorded during various legs at Site 504 with the temperature profile produced by a numerical model of active fluid circulation within the fault at $800 \mathrm{mbsf}$.

Despite these concerns about of the thermal regime in Hole 504B, this study underlines the poor knowledge that we still have of the hydrothermal activity within young oceanic crust. Additional and deeper sampling, as well as downhole measurements in Hole 540B and in other new crustal sites are clearly required.

\section{REFERENCES}

Adamson, A.C., 1985. Basement lithostratigraphy, Deep Sea Drilling Project Hole 504B. In Anderson, R.N., Honnorez, J., Becker, K., et al., Init. Repts. DSDP, 83: Washington (U.S. Govt. Printing Office), 121-127.

Alt, J.C., Kinoshita, H., Stokking, L.B., et al., 1993. Proc. ODP, Init. Repts., 148: College Station, TX (Ocean Drilling Program).

Alt, J.C., Laverne, C., and Muehlenbachs, K., 1985. Alteration of the upper oceanic crust: mineralogy and processes in Deep Sea Drilling Project Hole 504B, Leg 83. In Anderson, R.N., Honnorez, J., Becker, K., et al., Init. Repts. DSDP, 83: Washington (U.S. Govt. Printing Office), 217247.

Anderson, R.N., Honnorez, J., Becker, K., et al., 1985. Init. Repts. DSDP, 83: Washington (U.S. Govt. Printing Office).

Anderson, R.N., Zoback, M.D., Hickman, S.H., and Newmark, R.L., 1985. Permeability versus depth in the upper oceanic crust: in situ measurements in Deep Sea Drilling Project Hole 504B, eastern equatorial Pacific. 
In Anderson, R.N., Honnorez, J., Becker, K., et al., Init. Repts. DSDP, 83: Washington (U.S. Govt. Printing Office), 429-442.

Becker, K., 1989. Measurements of the permeability of the sheeted dikes in Hole 504B, ODP Leg 111. In Becker, K., Sakai, H., et al., Proc. ODP, Sci. Results, 111: College Station, TX (Ocean Drilling Program), 317325.

Becker, K., Foss, G., et al., 1992. Proc. ODP, Init. Repts., 137: College Station, TX (Ocean Drilling Program).

Becker, K., Langseth, M.G., Von Herzen, R.P., and Anderson, R.N., 1983. Deep crustal geothermal measurements, Hole 504B, Costa Rica Rift. J. Geophys. Res., 88:3447-3457.

Becker, K., Sakai, H., et al., 1988. Proc. ODP, Init. Repts., 111: College Station, TX (Ocean Drilling Program).

Cann, J.R., Langseth, M.G., Honnorez, J., Von Herzen, R.P., White, S.M., et al., 1983. Init. Repts. DSDP, 69: Washington (U.S. Govt. Printing Office).

Fisher, A.T., and Becker, K., 1991. The reduction of measured heat flow with depth in Hole 504B: evidence for convection of borehole fluids? Sci. Drill., 2:34-40.

Gable, R., Morin, R.H., and Becker, K., 1989. Geothermal state of Hole 504B: ODP Leg 111 overview. In Becker, K., Sakai, H., et al., Proc. ODP, Sci. Results, 111: College Station, TX (Ocean Drilling Program), $87-96$.

Gable, R., Morin, R., Becker, K., and Pezard, P., 1995. Heat flow in the upper part of the oceanic crust: synthesis of in-situ temperature measure- ments in Hole 504B. In Erzinger, J., Becker, K., Dick, H.J.B., and Stokking, L.B. (Eds.), Proc. ODP, Sci. Results, 137/140: College Station, TX (Ocean Drilling Program), 321-324.

Kinoshita, H., Furuta, T., and Pariso, J., 1989. Downhole magnetic field measurements and paleomagnetism, Hole 504B, Costa Rica Ridge. In Becker, K., Sakai, H., et al., Proc. ODP, Sci. Results, 111: College Station, TX (Ocean Drilling Program), 147-156.

Langseth, M.G., Mottl, M.J., Hobart, M.A., and Fisher, A., 1988. The distribution of geothermal and geochemical gradients near Site 501/504: implications for hydrothermal circulation in the oceanic crust. In Becker, K., Sakai, H., et al., Proc. ODP, Init. Repts., 111: College Station, TX (Ocean Drilling Program), 23-32.

Pezard, P.A., 1990. Electrical properties of mid-ocean ridge basalt and implications for the structure of the upper oceanic crust in Hole 504B. J. Geophys. Res., 95:9237-9264.

Pezard, P.A., and Anderson, R.N., 1990. In situ measurements of electrical resistivity, formation anisotropy, and tectonic context. Trans. SPWLA 31st Annu. Logging Symp., trans. M.

Date of initial receipt: 15 August 1994

Date of acceptance: 24 February 1995

Ms 148SR-141 